\title{
Akciğer kanserinde sağkalımı etkileyen klinikopatolojik özellikler
}

\author{
Clinicopathological factors related to survival in lung cancer
}

\author{
Umut KEFELİ, Bala Başak ÖVEN USTAALİOĞLU, Mahmut Emre YILDIRIM, Burçak ERKOL, Dinçer AYDIN, \\ Nur ŞENER, Alper SONKAYA, Özgür AÇIKGÖZ
}

\section{ÖZET}

Amaç: Akciğer kanserinde cinsiyet, tümör tipi ve diğer klinik özelliklerin sıklık ve mortalitedeki artışa sebep olduğu belirtilmiştir. Çalışmamızda, akciğer kanserli hastalarda klinik ve patolojik özelliklerin sağkalım üzerine etkilerini araştırdık.

Hastalar ve Yöntem: Merkezimizde 2005-2012 y1lları arasında akciğer kanseri tanısı almış 1031 olgunun dosyaları geriye dönük olarak incelendi.

Bulgular: Kadınlarda en sik rastlanan akciğer kanseri tipi adenokarsinom $(\% 42,2)$, erkeklerde en sik rastlanan tip skuamöz hücreli karsinom (\% 41,5) olarak bulundu. Akciğer kanserinin sigara ile ilişkisinde, tiplendirilemeyen küçük hücreli dış1 akciğer kanseri hariç, diğer akciğer kanseri hücreleri analiz edildiğinde,sigara içenlerde en sık skuamöz hücreli tip $(\% 40,7)$ ve sigara içmeyenlerde ise en sik histopatolojik tanı adenokarsinom (\% 39,8) olarak bulundu ve istatiksel olarak anlamlı bir ilişki saptand. Tüm grup için medyan sağkalım süresi 12,09 ay olarak saptandı. Tek değişkenli analizlerde 60 yaşın altında olma, Doğu Kooperatif Onkoloji Grubu Performans Skoru (The Eastern Cooperative Oncology Group Performance Score- (ECOG PS))'na göre iyi performans durumu (0-1), \% 5'den az kilo kayb1, primer tümörün büyüklüğü, metastaz olmaması ve erken evre hastalık faktörlerinin sağkalımı olumlu etkilediği saptandı. Çok değişkenli analizlerde sağkalımı olumlu etkileyen faktörler iyi performans durumu ve \% 5'den az kilo kaybı olarak bulundu.

Sonuç: Çalışmamız sonucunda, akciğer kanserinde cinsiyetler arasında histopatoloji tipinin farklılık gösterdiği saptandı. Sigara da histopatoloji tipini etkilemektedir. Ancak, cinsiyet, tümörün

Umut Kefeli (四), Alper Sonkaya, Özgür Açıkgöz

Tıbbi Onkoloji Anabilim Dal, Tip Fakültesi, Kocaeli Üniversitesi, Kocaeli, Türkiye

e-mail: ukefeli@yahoo.com

Bala Başak Öven Ustaalioğlu, Burçak Erkol

Tıbbi Onkoloji Kliniği, Haydarpasa Eğitim ve Araşstırma Hastanesi, İstanbul, Türkiye

Mahmut Emre Yıldırım, Dinçer Aydın, Nur Şener

Tıbbi Onkoloji Kliniği, Dr. Lütfi Kırdar Kartal Eğitim ve Araştırma Hastanesi, Istanbul, Türkiye

Gönderilme/Submitted: 02.11.2014

Kabul/Accepted: 07.12.2014 histopatoloji tipi ve sigara ile sağkalım arasında istatistiksel bir ilişkisi gösterilememiştir.

Anahtar kelimeler: Akciğer kanseri, Sağkalım, Klinikopatoloji

\section{ABSTRACT}

Objective: The increase in incidence and mortality due to lung cancer was related to gender, tumor type and clinical characteristics of the patients. The aim of this study was to evaluate the relationship between clinical and pathological characteristics of our patients related to survival.

Patients and Methods: Medical records of 1031 patients with lung cancer diagnosed between 2005 and 2012 at our institution were retrospectively analyzed.

Results: The most common histological type in women was adenocarcinoma (42.2\%) and in men was squamous type lung cancer $(41.5 \%)$. When the relation of histological type with smoking was analyzed by excluding undefined-non small cell lung cancer, squamous type lung cancer was the most common type $(40.7 \%)$ in smokers and adenocarcinoma was the most common type $(39.8 \%)$ in non-smokers and it was statistically significant. The median survival was 12,09 months. In univariate analysis, early age, The Eastern Cooperative Oncology Group Performance Score (ECOG PS) 0-1, weight loss less than 5\%, T stage, non-metastatic disease and early stage disease correlated with better survival. In multivariate analyses, good performance score and weight loss affected survival.

Conclusion: In our study, we found that histology types differ between both genders. Smoking also affects histological type. Despite these results, we could not find any statistically significant relationship between gender, histological type of the tumor, smoking and survival.

Keywords: Lung cancer, Survival, Clinicopathology

\section{Giriş}

Akciğer kanseri dünya genelinde hem kadınlarda hem de erkeklerde kansere bağlı ölüm nedenlerinin başında yer almaktadır. Akciğer ve prostat kanseri erkeklerde en sık 
görülen kanserler iken, kadınlarda akciğer kanseri dördüncü sırada gelmektedir [1]. A.B.D'de kansere bağlı mortalitenin en önde gelen nedenidir. A.B.D'de 2013 yllında 222.000'in üstünde yeni akciğer kanseri tanısı konmuştur ve bunların \% 80'i küçük hücreli dışı akciğer kanseridir (KHDAK) [2]. Medyan yaş yavaşça yükselmektedir ve şu an 69 olarak bulunmuştur [3]. Avrupa Birliği Ülkelerinde her y1l 381.500 yeni akciğer kanseri tanısı konulmaktadır ve bunların 341.800'ü ölüm ile sonuçlanmaktadır [4]. Türkiye'de Sağlık Bakanlığı verilerine göre, 1999 yılında akciğer kanseri insidans1 erkeklerde 7.8/100.000, kadınlarda 1.2/100.000' dir [5]. Ülkemizde yapılan bir araştırmada akciğer kanseri erkeklerde \% 90,5, kadınlarda \% 9,5 oranında gözlenmiş̧tir. Bu araştırmaya göre tüm Türkiye'de yaşa göre ayarlanan akciğer kanseri insidens hızının erkeklerde 74.2/100.000, kadınlarda ise 9.3/100.000 olduğu saptanmıştır. Yıllık tüm Türkiye'de tahmin edilen yeni olgu sayısı ise 29.314'dir [6].

Çeşitli çalışmalarda akciğer kanserinin görülme sıklığ ve mortalite artışında epidemiyolojik bulgulardaki değişimin rol oynadığı vurgulanmıştır. En belirgin değişiklikler kadın/ erkek oranı, tümör tipi ve yaş özelliklerinde saptanmıştır [7-9]. Sigara içen kadınlarda akciğer kanseri gelişiminin daha yüksek olduğu tartışılmaktadır ancak hem histolojik tiplerin dağılımı hem de tedavi yanıtı olarak kadınlarda akciğer kanserinin daha farklı bir hastalık olduğu görülmektedir [10-12].

$\mathrm{Bu}$ çalışmada akciğer kanserinde klinik ve patolojik özellikler ile sağkalımın değişimlerini belirlemeyi amaçladık.

\section{Hastalar ve Yöntem}

Ocak 2005 ve Aralık 2012 yılları arasında Dr. Lütfi Kırdar Kartal Eğitim ve Araştırma Hastanesi Tıbbi Onkoloji Kliniğinde toplam 1031 akciğer kanserli hastanın verileri retrospektif olarak değerlendirildi. Histopatolojik sınıflama için Dünya Sağlık Örgütü (DSÖ) sınıflaması kullanıldı [13]. Evreleme 2010 TNM evreleme sistemine göre yapıldı [14].

İstatiksel incelemeler SPSS for Windows 17.0 programı kullanılarak yapıldı. Verilerin değerlendirilmesinde ki-kare ve Kaplan-Meier sağkalım analiz testleri kullanıldı.

\section{Bulgular}

Çalışmaya alınan 1031 olgunun 133'ü (\% 12,9) kadın, 898'i (\% 87,1) erkek olarak bulunurken, kadın/erkek hasta oranı 1/6,75 olarak belirlendi. Hastaların yaş ortalaması $60,08 \pm 10,01$ (26-89) olarak bulundu. Kadın olguların yaş ortalaması $60,6 \pm 10,08$ (42-87), erkek olguların 60,1 \pm 9,8 (33-89) idi. Sigara kullananların oranı \% 84,5 olarak saptanırken kadınlarda bu oran \% 45,9, erkeklerde \% 90,4 olarak bulundu. Sigara içmeyen kadın hastaların oranı \% 54,1 iken, bu oran erkeklerde \% 9,6 olarak saptandı. Hastaların \% 55,9'unda, $\% 5$ 'den fazla kilo kaybı mevcuttu. Hastaların \% 14,9'unda ailede kanser öyküsü saptanırken, bu olguların \% 38 'sinde ailede akciğer kanseri olduğu belirlendi. Hastaların klinik özellikleri Tablo I'de gösterilmiştir.

Tablo I. Hastaların klinik karakteristikleri

\begin{tabular}{ll}
\hline Karakteristik & Hastalar (n=1031) \\
\hline Cinsiyet & \\
Erkek & $898(\% 87,1)$ \\
Kadın & $133(\% 12,9)$ \\
\hline Yaş & \\
Erkek & $60,1(33-89)$ \\
Kadın & $60,6(42-87)$ \\
\hline ECOG PS & \\
$0-1$ & $809(\% 78,5)$ \\
$2-4$ & $222(\% 21,5)$ \\
\hline Kilo kaybi & $454(\% 44,1)$ \\
Son 3 ayda $<\% 5$ & $577(\% 55,9)$ \\
Son 3 ayda $>\% 5$ & \\
\hline Ailede kanser öyküsü & $153(\% 14,9)$ \\
Var & $58(\% 38)$ \\
Akciğer kanseri & $95(\% 62)$ \\
Diğer & $878(\% 85,1)$ \\
Yok & E/K (\%) \\
Hiç içmemiș & $90,4 / 45,9$ \\
Eski veya halen & $9,6 / 54,1$ \\
\hline
\end{tabular}

Tüm grupta histopatolojik tanılara bakıldığında, tiplendirilemeyen KHDAK değerlendirme dişı bırakıldığında, yassı hücreli karsinom en sık (\% 40,2) tip olarak belirlendi. Yine tiplendirilemeyen KHDAK değerlendirme dışı bırakıldığında kadınlarda en sık rastlanan akciğer kanseri tipi adenokarsinom $(\% 42,2)$, erkeklerde en sık rastlanan tip yassı hücreli karsinom $(\% 41,5)$ olarak bulundu $(\mathrm{p}<0,05)$. Olguların tümör tipine göre dağılımı Şekil 1'de gösterilmiştir. Sigara ile ilişkiye bakıldığında tüm grupta sigara içenlerde ve içmeyenlerde sırasıyla en sık görülen histopatoloji tipi sırasıyla \% 31,2 ve \% 30.7 ile her ikisinde de tiplendirilemeyen KHDAK idi fakat istatiksel bir ilişki saptanmadı $(\mathrm{p}>0,05)$. Tiplendirilemeyen KHDAK çıkarılıp analiz yapıldığında sigara içenlerde en sık tip 
yass1 hücreli tip $(\% 40,7)$ ve sigara içmeyenlerde ise en s1k histopatolojik tanı adenokarsinom (\% 39,8) olarak bulundu ve istatiksel olarak anlamlı bir ilişki saptand $1(\mathrm{p}<0,05)$. Olguların yaşı ve aile öyküleri ile histopatolojik tanıları arasında anlamlı ilişki saptanamadı $(\mathrm{p}>0,05)$.

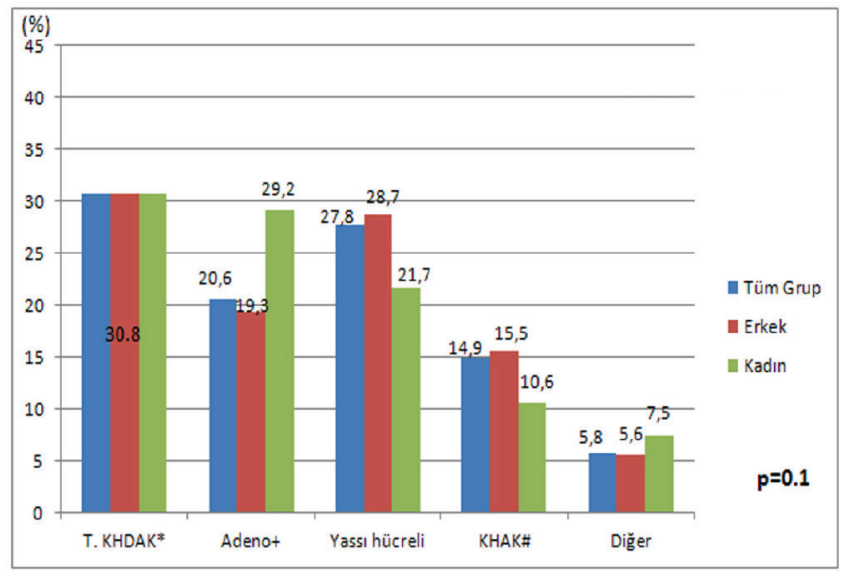

Şekil 1. Tüm grupta histopatolojik tiplerin oranları ve cinsiyete göre dağılımı

(*Tiplendirilmeyen küçük hücreli dış1 akciğer kanseri)

(+Adenokarsinom)

(\#Küçük hücreli akciğer kanseri)

Tüm grup için medyan sağkalım süresi 12,09 ay (\%95 CI: 10,9-13,1) olarak saptandı. Kadın olguların medyan sağkalım süreleri tüm grup için 14,3 ay (\%95 CI: 10,08- 18,6), erkek olguların sağkalım süresi 11,6 ay (\%95 CI: 10,4- 12,8) olarak saptanırken cinsiyetler arasında istatiksel fark saptanmadı ( $>0,05)$. KHDAK'lı olguların medyan sağkalımı 11,2 ay (\%95 CI: 9,9- 12,5) idi. KHDAK'lı kadın olguların medyan sağkalım süreleri 13,7 ay (\%95 CI: 8,9- 18,5) iken, erkeklerin medyan sağkalım süresi 10,9 ay (\%95 CI: 9,5- 12,2) olarak saptandı. KHAK'lı olguların medyan sağkalım süresi 22,3 ay (\%95 CI: 17,8- 26,8) idi. KHAK'lı kadın olguların medyan sağkalım süresi 17,6 ay (\%95 CI: 13,7- 21,5), erkek olguların medyan sağkalım süresi 22,3 ay (\%95 CI: 17,5- 27,1) olarak bulundu. Sigara içen hastalarda medyan sağkalım süresi 12,3 ay (\%95 CI: 11,4- 14,4) iken, içmeyenlerde bu süre 12,4 ay (\%95 CI: 9,5- 15,4) olarak saptand $(\mathrm{p}>0,05)$.

Tek değişkenli analizlerde tüm gruba bakıldığında cinsiyet, histopatolojik tanı ve sigara kullanımı ile sağkalım arasında istatiksel olarak anlamlı ilişki saptanmazken ( $>>0,05), 60$ yaşın altında olma, iyi performans durumu (ECOG PS:0-1), $\% 5$ 'den az kilo kaybı, primer tümörün büyüklüğü, metastaz olmaması ve erken evre hastalık faktörlerinin sağkalımı olumlu etkilediği saptandı $(p<0,05)$. Çok değişkenli analizlere bakıldığında ise tüm grupta sağkalımı olumlu etkileyen faktörler iyi performans durumu (ECOG PS:0-1) ve \% 5'den az kilo kaybı olarak bulundu $(\mathrm{p}<0,05)$. Sağkalımı etkileyen faktörler Tablo II'de, cinsiyet ve performans durumu ile sağkalım arasındaki ilişki Şekil 2 ve 3'de belirtilmiştir.

Tablo II . Sağkalıma etkili faktörlerin tek değişkenli analizi

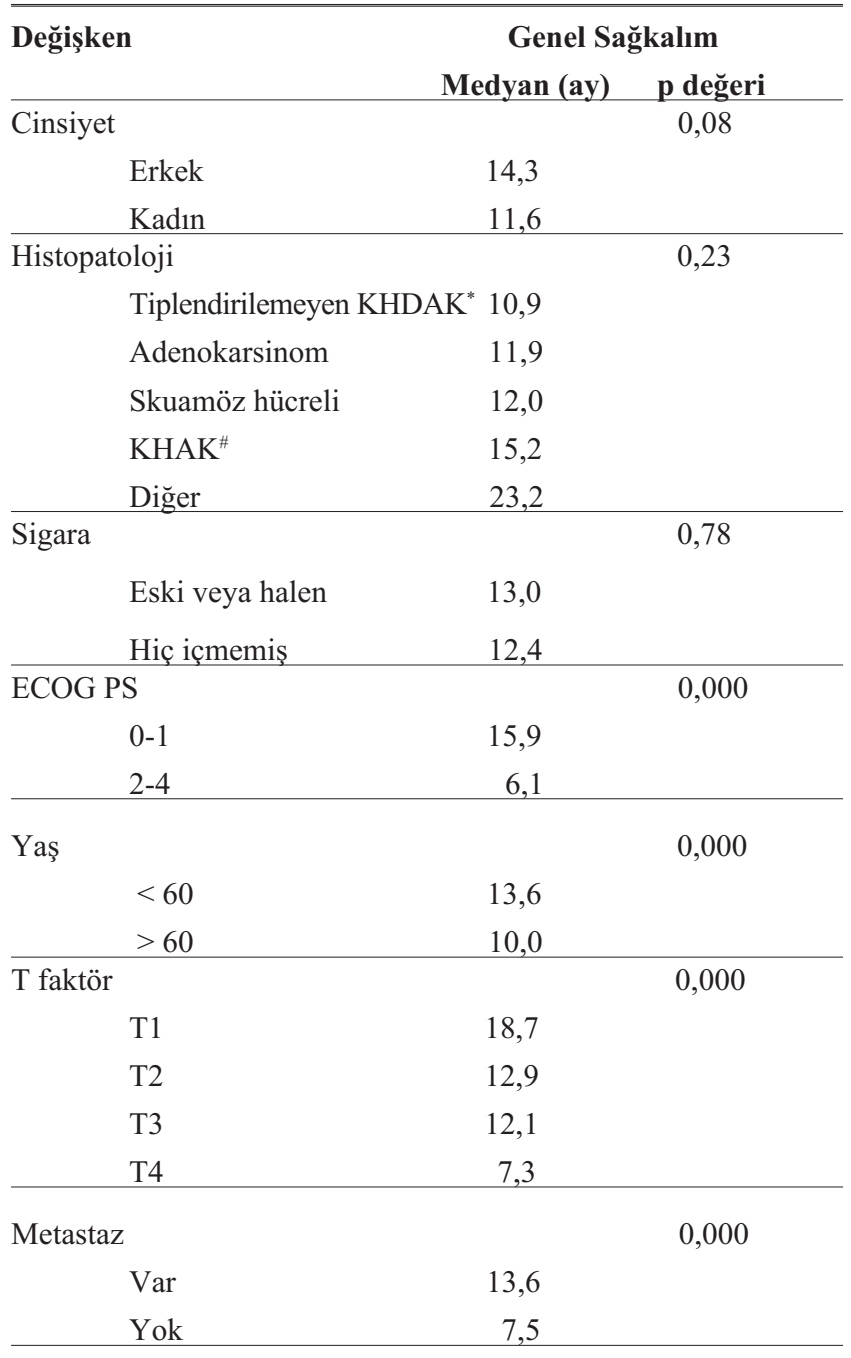

Evre

\begin{tabular}{ccc} 
KHDAK $^{*}$ & & 0,01 \\
Erken & 18,3 & \\
İleri & 12,7 & \\
KHAK $^{\#}$ & & 0,06 \\
Sinırl1 & 29,8 & \\
Yaygın & 19,6 & \\
\hline
\end{tabular}

Kilo kayb1

0,000

Son 3 ayda $<\% 5 \quad 20,5$

Son 3 ayda $>\% 5$

10,3

* KHDAK :Küçük hücreli dışı akciğer kanseri

\# KHAK : Küçük hücreli akciğer kanseri 


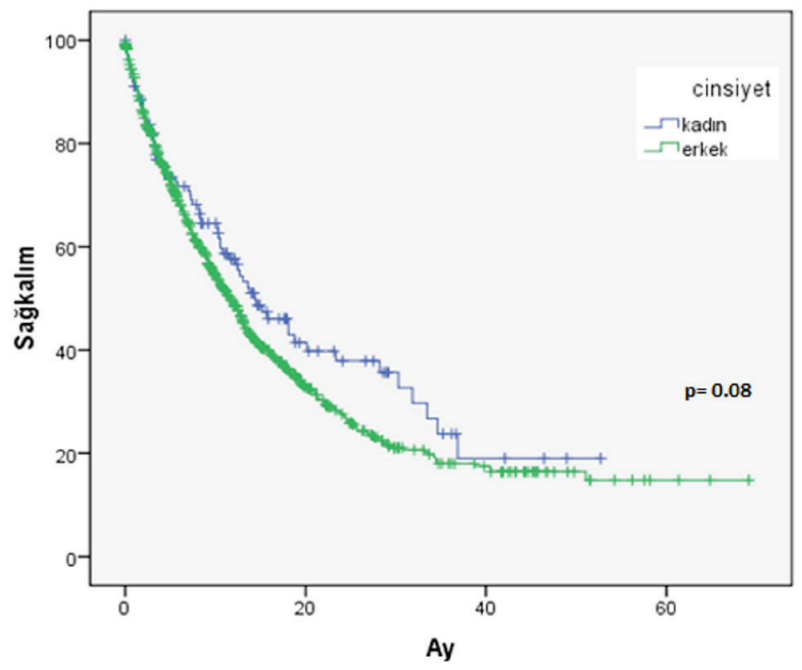

Şekil 2. Tek değişkenli analizde cinsiyetin sağkalım üzerine etkisi

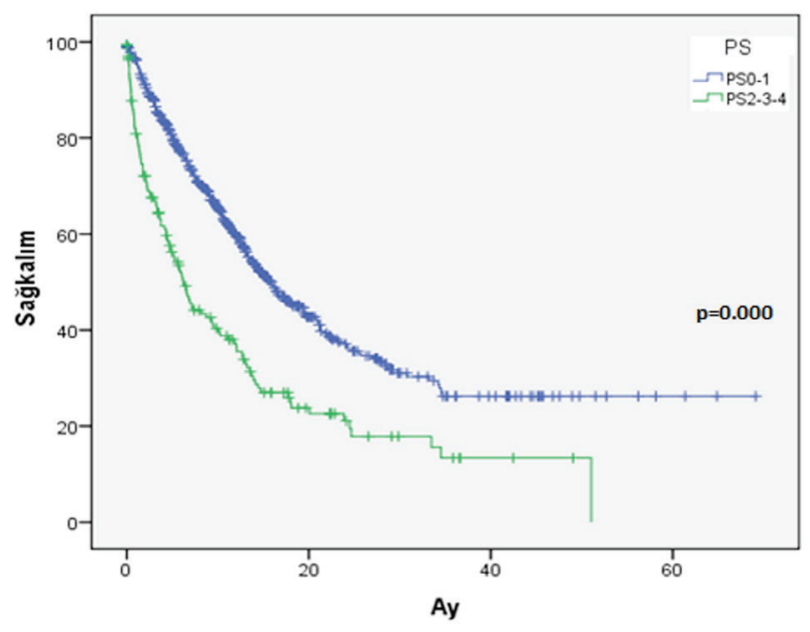

Şekil 3. Tek değişkenli analizde performans durumunun sağkalım üzerine etkisi

\section{Tartışma}

Akciğer kanseri kansere bağlı ölümlerin başında gelmektedir $[1,2]$. Kadınlarda akciğer kanserine bağlı ölümlerin artışına erkeklerde azalışının eşlik etmesi bu hastalıkta erkek/kadın oranını değiştirmiştir [15].Son yüzyılda meydana gelen bu değişikliklere epidemiyolojik bulgulardaki değişimler neden olmuştur. Bu değişiklikler sigara alışkanlıklarında değişime bağlanabileceği gibi cinsiyet, yaş ve tümör tipi özellikleri ile de ilişkilendirilebilinir [10,15-17].

Huhti ve arkadaşları, 20 yıllık bir süreçte akciğer kanserli kadın hasta oranının \% 6'dan \% 15'e yükseldiğini saptamışlardır [7,18]. Sağlık Bakanlığı verilerine göre, 1999 yılında akciğer kanseri insidansı erkeklerde 7.8/100.000, kadınlarda 1.2/100.000'dir [5]. Yakın zamanda ülkemizde yapılan tek merkezli bir araştırmada akciğer kanseri kadın hasta oranının giderek arttı̆̆ı ve 1992, 1998 ve 2004 yillarında sirasiyla \% 6,8, \% 8,5 ve \% 11,8 olduğu bulunmuştur [7]. Ülkemizde 7303 hasta ile yeni yapılan bir çalışmada ise tüm Türkiye'de yaşa göre ayarlanan akciğer kanseri insidens hızının erkeklerde 74,2/100,000, kadınlarda ise 9,3/100,000 olduğu saptanmıştır. Bu çalışmada, yıllık tüm Türkiye'de tahmin edilen yeni olgu sayısı ise 29,314 'dir. Tüm grupta ortalama yaş 60,7 $\pm 10,7$ (21-105), erkeklerde ortalama yaş $60,7 \pm 10,5$ ve kadınlarda 60,9 \pm 12,5 olarak bulunmuştur. İnsidens hızı erkeklerde 75-79 (572,9/100,000), kadınlarda ise 80-84 $(105,5 / 100,000)$ yaş aralığında tepe noktaya ulaşmaktadır [6]. Bizim çalışmamızda da bu yeni literatürlere uygun olarak kadın hasta oranı \% 12,9 olarak bulunmuştur ve bu bilgileri desteklemektedir. Bizim çalışmamızda hastaların yaş ortalaması $60,08 \pm 10,01$ (26-89) iken, kadın olguların yaş ortalaması $60,6 \pm 10,08$ (42-87), erkek olguların yaş ortalaması 60,1 \pm 9,8 (33-89) olarak bulundu.

Sigara akciğer kanserinde başlıca risk faktörüdür. Tanı anında hiç sigara içmemiş olan hastaların oranı yaklaşık \% 10'dur ve hiç sigara içmemiş akciğer kanserli olgularda kadın/erkek oranı 3/1'dir [19]. Çalışmamızda tüm grupta sigara içmeyenlerin oranı \% 15,5 olarak bulundu. Sigara içmeyen kadın hastaların oranı \% 54,1 iken, bu oran erkeklerde \% 9,6 idi ve kadın/erkek oranı 5,6/1 olarak saptandı. Bu durum sigara alışkanlığının ülkemizde kadınlarda erkeklere göre daha az olması (\%24/\%63) ile açıklanabilir [20]. Sigara alışkanlığındaki büyük farka rağmen çalışmamızda sigara kullanımının ve sigara alışkanlığının cinsiyete göre dağılımının sağkalım ile istatiksel olarak bir ilişkisi saptanamamıştır $(\mathrm{p}<0,05)$.

Akciğer kanseri epidemiyolojisinden belirgin değişiklikler tümör tipi sıklığında olmuştur. Huhti ve arkadaşlarının yaptığı bir çalışmada, 20 yıllık bir periyoda adenokarsinom oranının kadınlarda \% 27'den \%'de 46'ya, erkeklerde ise \% 11'den \%23'e yükseldiği bildirilmiştir [18]. Adenokarsinom sıklığında bu artışa rağmen çoğu ülkede yassı hücreli karsinom en sık görülen tip olmayı sürdürmektedir [8-16]. Sulu ve arkadaşlarının çalışmasında yassı hücreli karsinomun 1992-2004 yılları arasında en sık tip olmasına rağmen giderek azaldığ gözlenirken, adenokarsinomun belirgin olarak yükseldiği gözlenmektedir [7]. Göksel ve arkadaşlarının çalışmasında akciğer kanseri tümör tipleri sırasıyla yassı hücreli karsinom \% 29,2, tiplendirilemeyen KHDAK \% 23,3, adenokarsinom 
\% 16,9, KHAK \% 15,4 ve diğer \% 15,1 olarak bildirilmiştir ve tiplendirilemeyen KHDAK çıkarıldığında cinsiyete göre tümör tipi dağılımına bakıldığında; erkeklerde yassı hücreli karsinom \% 49,3, kadınlarda adenokarsinom \% 55,9 oran1 ile en sık tipler olarak bulunmuştur $(p<0,01)$ [6].Bizim çalışmamızda tiplendirilemeyen KHDAK \% 30,8, yassı hücreli karsinom \% 27,8, adenokarsinom \% 20,6, KHAK \% 14,9 ve diğer $\% 5,8$ olarak bulunmuştur. Tiplendirilemeyen KHDAK değerlendirme dışı bırakıldığında, yassı hücreli karsinom sıklığı \% 40,2 ile en sık tip olarak belirlendi. Yine tiplendirilemeyen KHDAK değerlendirme dışı bırakıldığında kadınlarda en sik rastlanan akciğer kanseri tipi adenokarsinoma $(\% 42,2)$, erkeklerde en sık rastlanan tip yassı hücreli karsinom $(\% 41,5)$ olarak bulundu ve istatiksel olarak cinsiyet ve histopatoloji arasında ilişki mevcuttu $(\mathrm{p}<0,05)$. Sigara ile ilişkiye bakıldığında tüm grupta sigara içenlerde en sık görülen patoloji tiplendirilemeyen KHDAK idi. Tiplendirilemeyen KHDAK çıkarılıp analiz yapıldığında sigara içenlerde en sık tip yassı hücreli tip $(\% 40,7)$ ve sigara içmeyenlerde ise en sık histopatolojik tanı adenokarsinom (\% 39,8) olarak bulundu ve istatiksel olarak anlamlı bir ilişki saptandı $(p<0,05)$. Akciğer kanseri tiplerinin dağılımındaki bu değişimi tek bir faktörle açıklamak mümkün değildir. Sigara içme alışkanlıklarındaki farklılıklar, farklı markalardaki kimyasal maddelerde değişiklikler, tedavi yöntemlerindeki farklar, akciğer kanserinde östrojen reseptör ekspresyonunun gösterilmiş olması, ekzojen/ endojen östrojenin etkileri gibi faktörler dağılımdaki bu değişikliğe neden olabilir [11,12,21,22].

Çalışmamızda tüm grup için medyan sağkalım süresi 12,09 ay olarak saptandı. Kadın olguların medyan sağkalım süreleri tüm grup için 14,3 ay erkek olguların sağkalım süresi 11,6 ay olarak saptanırken cinsiyetler arasında istatiksel fark saptanmadı. Tek değişkenli analizlerde tüm gruba bakıldığında cinsiyet, histopatolojik tanı ve sigara kullanımı ile sağkalım arasında istatiksel olarak anlamlı ilişki saptanmadı. 60 yaşın altında olma, iyi performans durumu (ECOG PS:0-1), \% 5'den az kilo kaybı, primer tümörün büyüklüğü, lenf nodu tutulumu, metastaz olmaması ve erken evre hastalık faktörlerinin sağkalımı olumlu etkilediği saptandı. Çok değişkenli analizlere bakıldığında ise tüm grupta sağkalımı olumlu etkileyen faktörler iyi performans durumu (ECOG PS:0-1) ve $\% 5$ 'den az kilo kaybı olarak bulundu. Bu faktörlerin daha önceki çalışmalarda da sağkalım ile ilişkisinin olduğu gösterilmiştir [23,24]. Çalışmamızda kilo kaybı olan hastalarda medyan sağkalım 10,3 ay olarak bulunurken, kilo kaybı olmayan hastalarda 20,5 ay olarak bulunmuştur. Kilo kaybının daha ileri evre hastalığı olanlarda gözüktüğü için kötü prognoz kriteri olduğu belirtilirken ek olarak bu hastalarda kemoterapi toleransinın bozulmasının, artmış kemoterapi toksisitesinin ve kemoterapi uygulama sayısındaki azlığın buna katkıda bulunduğu belirtilmektedir [25].Perfomans skoru da birçok çalışmada bağımsız prognostik faktörü olarak bulunmuştur $[24,26]$. Çalışmamızda PS 0-1 olan hastalarda medyan sağkalım 15,9 ay iken, performansı kötü olan hastaların medyan sağkalımı 6,1 ay olarak bulunmuştur.

Çalışma ile ilgili veriler incelendiğin de çalışmanın kısıtlamaları da göz önünde alınmalıdır. İlk olarak çalışmanın tek merkezli olarak yapıldığı ve belli bir bölgedeki sosyodemografik özelliklere sahip hastalarda yapıldı̆̆ 1 göz önünde bulundurulmalıdır. Diğer bir kısıtlama olarak sigara alışkanlığının süresinin çalışmaya dahil edilmediği unutulmamalıdır. En son fakat en önemli olabilecek kısıtlama olarak da çalışmaya alınan hastalarının histopatolojik tanısında tiplendirilemeyen KHDAK tipinin (diğer çalışmalarda da mevcut olmasına rağmen) fazla oluşudur. Bu faktör direkt olarak sonuçları etkileyebilmektedir.

Sonuç olarak, son yıllardaki gelişmelere rağmen akciğer kanseri hala önde gelen mortalite nedenlerindendir. KHDAK'de kadın cinsiyet, histopatolojik olarak adenokarsinomun daha çok görüldüğü, daha az sigara içen bir grup olarak ortaya çıkmaktadır. Histopatolojik tipler cinsiyete ve sigara kullanımına göre farklılık göstermektedir. Çalışmamızdaki veriler daha önceki araştırmalarla benzer sonuçlar vermektedir. Bunların sağkalıma etki edeceği düşünülmelidir. Sağkalım analizlerinde anlamlı fark saptanmasa da özellikle iki cinsiyet arasındaki moleküler düzeydeki olası farklılıkların saptanması daha belirgin olarak hedeflenmiş tedavilerin uygulanmasına ve daha yararlı sonuçların alınmasına katkıda bulunacaktır. Gelecekteki yaklaşımlarımıza yön verebilmek için bu bilgilerin 1şığında daha kapsamlı çalışmalara gerek vardır.

\section{Kaynaklar}

1. Ferlay J, Autier P, Boniol M, Heanue M, Colombet M, Boyle $\mathrm{P}$. Estimates of the cancer incidence and mortality in Europe in 2006. Ann Oncol 2007;18:581-92.

2. Siegel R, Naishadham D, Jemal A. Cancer statistics, 2013. CA Cancer J Clin 2013;63:11-30. doi:10.1093/annonc/mdl498

3. Owonikoko TK, Ragin CC, Belani CP, et al. Lung cancer in 
elderly patients: an analysis of the surveillance, epidemiology, and end results database. J Clin Oncol 2007;25:5570-7. doi:10.1200/JCO.2007.12.5435

4. Boyle P, Ferlay J. Cancer incidence and mortality in Europe, 2004. Ann Oncol 2005;16:481-8. doi: 10.1093/annonc/mdi098

5. The Ministry of Health Department of Cancer Control. Cancer Control Programme and Cancer Statistics in Turkey (19951999). Ankara 2002: 135-61.

6. Türk Toraks Derneği 13. Y1llık Kongresi. http://www.toraks. org.tr/SunuMerkezi/?s=24223C5F5856265D29 Erişim tarihi : 22.08.2014.

7. Sulu E, Damadoğlu E, Nergiz S, et al. Primer akciğer kanserinde tümör tipi ve cinsiyet dağılımı değişiyor mu? 2004 yılı sonuçlarının daha önceki yıllar ile karşılaştırılması. Tuberk Toraks 2007;55:59-63.

8. Makitaro R, Paakko P, Huhti E, Bloigu R, Kinnula VL. An epidemiological study of lung cancer: History and histological types in a general population in Northern Finland. Eur Respir J 1999; 13: 436-40.

9. Levi F, Franceschi S, La Vecchia C, Randimbison L, Te VC. Lung carcinoma trends by histologic type in Vaud and Neuchatel, Switzerland, 1974-1994. Cancer 1997; 79: 90614. doi:10.1002/(SICI)1097-0142(19970301)79:5<906::AIDCNCR6>3.0.CO;2-9

10. Radzikowska E, Glaz P, Roszkowski K. Lung cancer in women: Age, smoking, histology, performance status, stage, initial treatment and survival. Population-based study of 20561 cases. Ann Oncol 2002; 13: 1087-93. doi: 10.1093/annonc/mdf187

11. Patel JD, Bach PB, Kris MG. Lung cancer in US women, a contemporary epidemic. JAMA 2004; 291: 1763-8. doi:10.1001/jama.291.14.1763

12. Sen E, Kaya A, Erol S, Savas I, Gonullu U. Kadınlarda akciğer kanseri: Klinik özellikler ve sağkalıma etkili faktörler. Tuberk Toraks 2008;56:266-74.

13. Brambilla E, Travis WD, Colby TV, Corrin B, Shimosato Y. The new World Health Organization classification of lung tumours. Eur Respir J 2001;18:1059-68. doi: 10.1183/09031936.01.00275301

14. Edge SB, Byrd DR, Compton CC, Fritz AG, Greene FL, Trotti A, (editors).AJCC TNM staging system for lung cancer. AJCC Cancer Staging Handbook, 7th edition. New York: Springer, 2010:299-323.
15. Thomas L, Doyle LA, Edelman MJ. Lung cancer in women: emerging differences in epidemiology, biology, and therapy. Chest 2005;128:370-81. doi: 10.1378/chest.128.1.370

16. Janssen-Heijnen MLG, Coebergh JWW. The changing epidemiology of lung cancer in Europe. Lung Cancer 2003; 41: 245-58. doi: 10.1016/S0169-5002(03)00230-7

17. Harkness EF, Brewster DH, Kerr KM, Fergusson RJ, MacFarlane GJ. Changing trends in incidence of lung cancer by histologic type in Scotland. Int J Cancer 2002; 102: 179-83. doi: 10.1002/ijc.10661

18. Huhti E, Sutinen S, Reinila A, Poukkula A, Saloheimo M. Lung cancer in a defined geographical area: History and histological types. Thorax 1980; 35: 660-67. doi: 10.1136/thx.35.9.660

19. Belani CP, Marts S, Schiller J, Socinski MA. Women and lung cancer: Epidemiology, tumor biology, and emerging trends in clinical research. Lung Cancer 2007; 55: 15-23. doi:10.1016/j. lungcan.2006.09.008

20. Utkaner G, Y1lmaz U, Celikten E, Gursoy M. Primer akciğer kanserli 116 kadın olgunun analizi. Solunum Hastalıkları 1996; 7: 1-9.

21. Montesinos J, Bare M, Dalmau E, et al. The changing pattern of non-small cell lung cancer between the 90 and 2000 decades. Open Respir Med J 2011;5:24-30. $10.2174 / 1874306401105010024$

22. Fu JB, Ying Kau T, Severson RK, Kalemkerian GP. Lung cancer in women, analysis of the national surveillance, epidemiology, and end results database. Chest 2005; 127: 76877. doi: 10.1378/chest.127.3.768

23. Finkelstein DM, Ettinger DS, Ruckdeschel JC. Long-term survivors in metastatic non-small-cell lung cancer: an Eastern Cooperative Oncology Group Study. J Clin Oncol 1986;4:702-9.

24. Martins S, Pereira J. Clinical factors and prognosis in nonsmall cell lung cancer. Am J Clin Oncol 1999;22:453-7. doi: 10.1097/00000421-199910000-00006

25. Ross PJ, Ashley S, Norton A, et al. Do patients with weight loss have a worse outcome when undergoing chemotherapy for lung cancers? Br J Cancer 2004;90:190511. doi: $10.1038 /$ sj.bjc. 6601781

26. Capewell S, Sudlow MF. Performance and prognosis in patients with lung cancer. Thorax 1990; 45: 951-6.doi:10.1136/ thx. 45.12 .951 